\title{
TENUN GEDOGAN DERMAYON
}

\author{
Oleh Ria Intani T. \\ Balai Pelestarian Sejarah dan Nilai Tradisional Bandung \\ Jln. Cinambo No. 136 Ujungberung Bandung \\ Email: ria_intani@yahoo.com
}

Naskah disetujui: 12 Februari 2010

\begin{abstract}
Abstrak
Penelitian ini dilakukan untuk menggali pengetahuan tentang tenun gedogan Dermayon. Tentang bahan-bahan, alat yang digunakan, teknik pembuatan, sampai dengan sistem produksi, konsumsi, dan distribusi. Penenun gedogan berada di Desa Juntikebon, Kecamatan Juntinyuat. Penelitian dilakukan dengan menggunakan metode deskriptif dengan pendekatan kualitatif. Hasil penelitian menunjukkan bahwa kegiatan bertenun di Juntikebon merupakan industri rumahan. Sepintas sulit menunjukkan angka pasti jumlah pengrajin. Penyebabnya adalah nyaris semua pengrajin adalah pengrajin sambilan. Mereka bertenun setelah bersawah dan bilamana ada waktu. Ilmu sekaligus alatnya merupakan warisan orang tua. Produksinya berupa selendang yang pada zamannya berfungsi sebagai alat gendong. Keterbatasan modal dibarengi ketiadaan generasi penerus di dalam keluarga menjadi penyebab keterbatasan dalam berproduksi. Ketiadaan promosi berakibat masyarakat awam terhadap tenun gedogan. Penyaluran hasil produksi lebih mengandalkan pada bakul, mereka adalah pembeli sekaligus penjual.
\end{abstract}

Kata kunci: tenun gedogan, pekerjaan sambilan, selendang, bakul.

\section{Abstract}

This research was conducted to explore the knowledge of gedogan Dermayon weaving. This research includes materials, equipment used, manufacturing technique, production system, consumption, and distribution. Gedogan weavers lives in the Juntikebon village, Juntinyuat-Indramayu. Research carried out by using descriptive method with qualitative approach. The results showed that weaving activity in Juntikebon is a home industry. There are no definite figures that can indicate the number of weavers. The reason is almost all weavers are sideline weavers. They weave after doing wet-rice cultivation, and when they have time to do it. Science and tools are inherited from parents. Production is shawl that at that time used to be a carrying tool. Limited capital accompanied by lack of continuer generation in the family cause the limitations in production. Lack of promotion resulted the commonness society about gedogan weaving. That is why the distribution of production realy more on wholesaler, they are buyers and sellers.

Keywords: gedogan weaving, sideline jobs, shawl, wholesaler. 


\section{A. PENDAhuluan}

Begitu kain dikenal dalam kehidupan manusia, sejak itulah kain menjadi bagian dari kehidupan manusia yang sangat primer. Kedudukannya dapat dikatakan sejajar dengan pangan dan papan. Hal ini dapat dipahami karena kain berfungsi sebagai penutup dan pelindung tubuh. Fungsi kain berkembang bentuknya menjadi pakaian dan bahkan kemudian bisa meluas lagi, menjadi alat gendong, perlengkapan desain interior, dan lain sebagainya. R. Brown menjelaskan dalam teori fungsional bahwa fungsi mengandung tiga pengertian, yang satu di antaranya adalah goal 'tujuan'. Intinya adalah bahwa segala sesuatu yang diciptakan memiliki tujuan atau manfaat. Terlepas dari fungsinya, berbagai wujud kain dari yang paling sederhana hingga yang rumit mendapat sentuhan teknologi, harus melalui proses tenun.

Menurut Zainal Arifin, kain dalam arti kain yang ditenun secara manual dan mengikuti tradisi, dimiliki oleh setiap suku bangsa yang pernah ada di muka bumi. Bangsa Indonesia boleh berbangga dalam hal tenun, karena salah satu kain tenun yang dihasilkan dari wilayah Indonesia bagian Timur diakui dunia sebagai kain tenun ikat terbaik. Tenun yang dimaksud adalah tenun buatan Nusa Tenggara. Penilaian tersebut diberikan pada saat berlangsung Pameran Kerajinan Internasional (International and Nasional Crafts Conference and Exhibition). Pameran tersebut berlangsung di Jakarta tahun 1985 dan diikuti oleh dua belas negara. Komentar lain muncul dari seorang pengamat tekstil dunia, Joseph Fisher
(1991:243), menurutnya seni tenun yang paling kaya dan canggih yang pernah ada di dunia dihasilkan di Indonesia.

Menurut Ensiklopedi Nasional Indonesia jilid 16 (1991: 242), kain tenun adalah hasil kerajinan berupa kain. Kain tersebut dapat dibuat di antaranya dari serat kayu, kapas, dan sutera. Caranya dengan memasukkan benang yang sejajar dengan lebar kain (pakan) secara melintang pada benang yang sejajar dengan panjang kain (lusi). Kain tenun dibuat dengan menggunakan seperangkat alat tenun yang umumnya dikerjakan oleh kaum wanita. Bertenun merupakan aktivitas budaya manusia sejak zaman prasejarah. Asia Timur, India, dan Asia Barat adalah beberapa di antara pusatpusat budaya pertenunan kuno. Dari wilayah tersebut kepandaian bertenun disebarkan ke berbagai masyarakat di belahan dunia, termasuk di antaranya Indonesia.

Kegiatan bertenun di Indonesia dikenal sejak beberapa abad sebelum Masehi. Kepandaian dalam bertenun merupakan kelanjutan kepandaian dalam menganyam daun-daunan maupun serat kayu untuk dibuat wadah atau busana. Kepandaian bertenun tersebut lalu dikembangkan, yang mengarah pada peningkatan kualitas yang mencakup bahan, tata warna, dan motif. Adakalanya tata warna dan motif dalam tenun tidak terlepas dari karakter dan falsafah hidup masyarakat pendukungnya. Biasanya dalam tata warna dan motif-motif tenun terdapat kandungan makna. Dengan kata lain, tenun merupakan benda simbolis. Simbol dirumuskan oleh White sebagai nilai atau arti yang ditentukan oleh 
orang yang menggunakannya, simbol dapat berbentuk suatu objek material, warna, bunyi, bau, gerak dari suatu objek, rasa (Nina Isniawati, 1988: 21).

Awal perkembangan tenun di Jawa Barat sulit dilacak. Hanya saja dalam naskah Sanghyang Siksa Kandang Karesian disebutkan bahwa pada masyarakat terdapat kelompok yang ahli dalam bidang perkainan. Selanjutnya dalam naskah yang ditulis pada tahun 1518 Masehi tersebut, disebutkan ada beberapa macam corak tenun, yakni: kembang muncang, gagang senggang, sameleg, seumat sahurun, anyam cayut, sigeji, pasi-pasi, kalangkang ayakan, poleng rengganis, jayanti, cecempaan, papara-nakan, mangin haris, siliganti, boeh siang, bebernatan, papakanan, surat awi, parigi nyengsoh, gaganjar, lusian besar, kampuh jayanti, hujan riris, laris, boeh alus, dan ragen panganten. Dan dari sini dapat dipastikan bahwa teknologi tenun sudah dikenal. Sayangnya tidak ada gambaran yang komprehensif tentang perkembangan teknologi tenun itu. Meskipun demikian diperkirakan teknologi tenun sudah dimulai sejak jaman perundagian, diperkuat dengan adanya Situs Pasir Angin di Bogor Jawa Barat.

Bukti lain bahwa tenun telah dikenal lama di Jawa Barat dapat dilihat pada ilustrasi cerita rakyat Jawa Barat yang mengilustrasikan seorang perempuan sedang menenun. Tokoh yang paling terkenal adalah Dayang Sumbi dalam legenda Gunung Tangkuban Perahu. Kata dayang pada nama tokoh cerita itu merupakan kata sandang yang berasal dari danghyang. Adapun kata sumbi secara harfiah berarti sepotong bambu kecil yang digunakan untuk pembatas lebar tenunan. Oleh karenanya Dayang Sumbi dapat dikatakan sebagai simbol perempuan yang pekerjaannya menenun. Lagu ninun juga menguatkan adanya anggapan bahwa kegiatan menenun di Jawa Barat sudah berlangsung lama dan mentradisi. Bukti lain dapat dibaca dalam kamus istilah busana yang ditulis Rigs. Dalam kamus tersebut disebutkan bahwa bahan yang digunakan untuk pakaian adalah boeh 'kain kafan', batik, dan tinun 'tenun'.

Pada zamannya, Majalaya pernah mengalami masa kejayaan melalui produk sarungnya. Kini semuanya tinggal kenangan. Proses globalisasi yang menyentuh dunia usaha berakibat pada peningkatan daya saing antara produsen tekstil modern dengan tradisional. Beberapa daerah penghasil tenun yang lain pun menunjukkan ke arah kebangkrutan. Hal ini tentu saja mengancam kelangsungan warisan budaya. Padahal era otonomi menuntut setiap daerah untuk mengungkapkan khasanah budaya sebagai salah satu simbol kebanggaan daerah. Dilatar-belakangi oleh adanya kekhawatiran seperti itu maka penelitian terhadap tenun dilakukan

Penelitian ini dilakukan untuk menggali pengetahuan tentang tenun gedogan dan memperkaya data kebudayaan yang ada di BPSNT Bandung. Lokasi penelitian di Desa Juntikebon, Kecamatan Juntinyuat, Kabupaten Indramayu. Materi yang diteliti meliputi: pengertian tenun, sejarah perkembangan teknologi tenun di Jawa Barat, bahan untuk membuat tenun, alat yang digunakan untuk menenun, proses menenun sampai dengan ragam hias (motif dan warna), serta sistem 
produksi, konsumsi, dan distribusi tenun.

Tipe penelitian adalah deskriptif dengan pendekatan kualitatif. Deskripsi adalah menggambarkan suatu hal sesuai dengan keadaan yang sebenarnya (kesan pancaindra terhadap objek) (Sumijati As., 2007: 12). Pendekatan kualitatif adalah suatu cara yang digunakan untuk menyelidiki dan memecahkan masalah yang tidak terbatas pada pengumpulan dan penyusunan data melainkan meliputi analisa dan interpretasi data sampai kepada kesimpulan yang didasarkan atas penelitian (Surakhmad, 1928:139). Langkah-langkah yang dilakukan dalam penelitian ini meliputi: studi pustaka, menyusun proposal penelitian, menyusun alat pengumpul data, kegiatan lapangan berupa observasi (pengamatan) dan wawancara, mengolah data, melakukan analisis, dan menyusun laporan.

\section{B. HASIL DAN BAHASAN}

\section{Deskripsi Wilayah}

Desa Juntikebon berjarak hanya nol kilometer ke pusat Pemerintahan Kecamatan Juntinyuat. Untuk menuju ke Desa Juntikebon dapat ditempuh dengan kendaraan angkutan umum selama 15 menit. Adapun jarak ke pusat Pemerintahan Kabupaten Indramayu berkisar 22 kilometer. Lama tempuh dengan berkendaraan umum berkisar 45 menit.

Mayoritas penduduk Juntikebon bermatapencaharian sebagai petani pemilik dan buruh tani sawah yaitu sebanyak 759 orang. Selain itu, disebutkan pula, ada 65 orang pengrajin namun tidak ada angka pasti untuk pengrajin tenun (Data Potensi Desa Juntikebon Tahun 2008).

\section{Pengertian Tenun}

Kata tenun berasal dari kata textere (bahasa Latin) yang berarti menenun. Kata tersebut kemudian menjadi dasar dari kata dalam bahasa Inggris textile dan kata dalam bahasa Indonesia tekstil. Menenun adalah mengolah bahan baku dari benang menjadi benda anyaman yang selanjutnya disebut kain tenun. Istilah kain tenun dimaksudkan untuk membedakan bermacam jenis kain yang proses pembuatannya tidak dengan ditenun. Dalam pengertian teknologi tekstil ada yang disebut kain rajut, kain kempa, dan lain sebagainya.

Menenun adalah menganyam benang-benang pakan (benang yang sejajar dengan lebar kain) pada benangbenang lusi (benang yang sejajar dengan panjang kain). Adapun pengertian menganyam adalah menyilangkan benang pakan pada benang-benang lusi dengan cara tertentu.

Ada tiga jenis alat tenun yang digunakan di Indonesia, yaitu:

- Gedogan, alat tenun yang masih sederhana yang cara penggunaannya adalah dengan cara memangku atau menggendong alatnya sambil duduk di lantai.

- ATBM, alat tenun bukan mesin, yaitu alat tenun yang menggunakan rangka kayu yang gerakan mekaniknya dilakukan oleh tenaga manusia.

- ATM, alat tenun mesin, alat ini merupakan alat tenun termodern. 


\section{Sejarah Perkembangan Teknologi dan Industri Tenun di Jawa Barat}

Sebelum masa kemerdekaan, di Jawa Barat dan bahkan di seluruh tanah air belum dikenal alat tenun yang lain selain hanya gedogan. Setelah masa kemerdekaan, Lembaga TIP (Textiel Inrichting Bandung) menciptakan ATBM.

Tahun 1970-an pemerintah mulai mendatangkan ATM. Semenjak itu mulai tumbuh perusahaan tekstil swasta yang menggunakan ATM berteropong. Tahun 1980-an pabrik pembuat mesin tenun mulai memperkenalkan mesin baru tanpa teropong (shuttleless). Tahun 1980 hingga sekarang berkembang teknologi pertenunan tanpa teropong.

Sebelum masa kemerdekaan, pusat kegiatan pertenunan di Jawa Barat tersebar di Kabupaten Bandung, Garut, Tasikmalaya, dan Cirebon dengan jenis produksinya di antaranya sarung, bordir, batik, dan handuk. Setelah masa kemerdekaan, Kabupaten Bandung menjadi pusat pertumbuhan tekstil nasional. Lebih dari 50\% industri tekstil Indonesia berada di Kabupaten Bandung, tepatnya di Majalaya. Namun demikian secara perlahan-lahan industri tekstil Jawa Barat mengalami penurunan bahkan mengalami masa krisis.

Saat ini, kegiatan bertenun yang tersisa di Jawa Barat di antaranya di Indramayu, tepatnya di Desa Juntikebon. Beberapa orang perempuan di atas usia 45 tahun menggeluti pekerjaan menenun dengan alat gedogan. Meskipun jumlah pengrajinnya hanya dalam "bilangan jari" namun angka pasti masih sulit diperoleh. Hal ini lebih disebabkan sebagian besar dari pengrajin menjadikan pekerjaan menenun hanya sebagai pekerjaan sampingan. Mereka menenun kalau ada waktu senggang. Konon, keberadaan pengrajin tenun gedogan di Desa Juntikebon memiliki keterkaitan dengan Desa Pondoh, desa tetangganya. Diceritakan bahwa pada zamannya pengrajin tenun gedogan di Desa Pondoh lebih dikenal. Buah karya mereka dikenal dengan istilah babaran Pondoh. Suatu ketika ada orang Desa Juntikebon yang berkunjung ke Desa Pondoh kemudian membeli selendang dari pengrajin tenun di sana. Sepulangnya, ia merasa tertarik untuk membuat selendang sendiri. Sejak saat itu selendang tersebut dijadikan contoh untuk selanjutnya dikembangkan di Desa Juntikebon.

\section{Bahan Tenun}

Tenun gedogan dibuat dari benang nilon. Benang nilon yang digunakan adalah benang kualitas 1 dan 2. Kualitas 1 digunakan untuk benang lusi, sedang-kan kualitas 2 digunakan untuk benang pakan. Penggunaan benang untuk benang pakan lebih dipentingkan pada ragam warnanya ketimbang kualitasnya. Hampir semua warna benang digunakan, di antaranya merah, kuning, hitam, hijau, orange, putih, pink, dan biru.

Tenun gedogan identik dengan selendang oleh karena sejak kehadirannya hingga saat ini hanya selendang yang diproduksi. Satu helai selendang berukuran panjang (P) 3 meter dan lebar (L) 50 sentimeter. Dengan ukuran seperti itu, $1 \mathrm{~kg}$ benang dapat menghasilkan 2 helai selendang. Demi keperluan membuat selendang, salah seorang pengrajin biasa membeli benang sebulan sekali. Sekali 
pembelian berkisar $20 \mathrm{~kg}$. Benang sebanyak itu biasanya mencakup 5 warna. Benang dibeli dari Plered Cirebon, di tempat industri rumahan pembuatan topi dan kaos. Benang dari Plered kualitasnya dianggap lebih bagus karena tidak mudah putus. Pembelian benang dilakukan dengan langsung datang ke tempat dan dibayar secara tunai. Hal ini disebabkan jumlah benang yang dibeli tidak banyak. Kontak lewat telepon sekadar untuk memeriksa ada atau tidak ada benang. Benang nilon dibeli dalam bentuk gulungan. Meskipun demikian, jumlah benang yang dibeli tidak dihitung dari jumlah gulungannya melainkan ditimbang beratnya dengan takaran kilogram.

\section{Peralatan Tenun}

Gedogan adalah nama dari alat yang digunakan untuk menenun. Gedogan dimiliki oleh setiap pengrajin tenun. Alat ini biasanya dibuat oleh tukang kayu. Bahan yang paling bagus untuk membuat gedogan adalah kayu pohon kelapa. Gedogan memiliki beberapa bagian. Satu bagian yang mudah rusak yaitu bagian cacak. Cacak yang rusak biasa diperbaiki oleh tukang kayu. Gedogan biasa dibuat dalam jangka waktu sebulan. Sementara itu, untuk membuat atau memperbaiki cacak yang rusak memakan waktu lima hari. Pengrajin tenun biasanya tidak membuat gedogan sendiri, gedogan yang digunakan merupakan warisan dari orang tuanya. Hanya saja gedogan yang diperoleh dari warisan biasanya tanpa cacak karena sudah rusak. Dengan demikian pengrajin tinggal membuatkan cacak-nya pada tukang kayu.
Ragam alat menenun di antaranya adalah: pajal, kluntungan benang, undar jantra, pamanen, teropong, dan gedogan. Keseluruhan alat tersebut merupakan satu rangkaian alat menenun yang tidak dapat dipisahkan antara satu dan lainnya. Adapun gedogan itu sendiri terdiri atas beberapa bagian yang masing-masing bagiannya memiliki nama. Bagianbagian yang dimaksud di antaranya: por, apit, suri, dayan (papan), dan cacak. Keseluruhan bagian tersebut juga merupakan satu kesatuan dalam alat tenun gedogan yang tidak dapat dipisahkan antara satu dan lainnya.

Ragam alat menenun tersebut di atas memiliki fungsi sebagai berikut:

- Pajal, alat ini terbuat dari bambu, gunanya untuk menggulung benang dari undar jantra melalui proses nglerek.

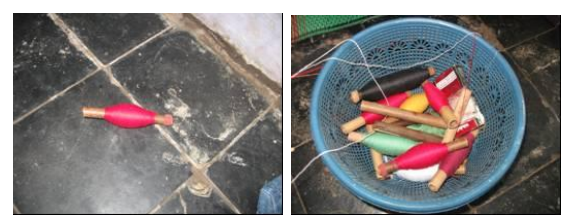

Sumber: Penelitian, 2009

- Undar, alat ini menyerupai kincir, terbuat dari bambu, kayu, dan benang. Alat ini biasanya dibuat sendiri. Undar merupakan pasangan jantra. Undar jantra berfungsi untuk nglerek.

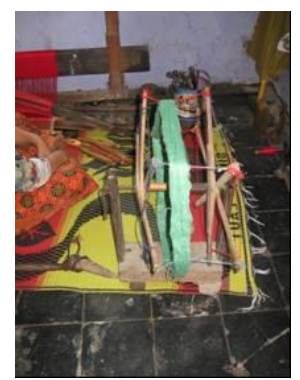

Sumber: Penelitian 2009 
- Jantra, alat ini terbuat dari kayu dan roda. Jantra merupakan pasangan undar. Undar jantra berfungsi untuk nglerek.

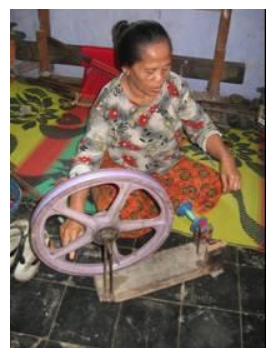

Sumber: Penelitian 2009

- Pamanen, digunakan untuk menggulung benang dari kluntungan. Lebar benang yang digulung sesuai ukuran kain yang diinginkan. Alat ini biasanya dibuat oleh tukang kayu, waktu pembuatannya berkisar 1 minggu.

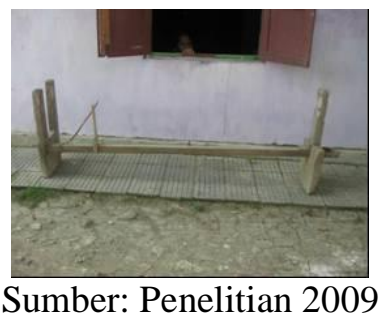

- Kluntungan benang.

- Teropong, berfungsi untuk memasukkan benang yang ada di pajal pada saat menenun.

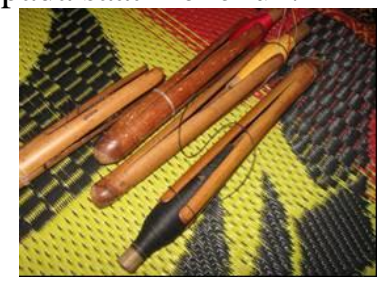

Sumber: Penelitian 2009

- Gedogan, alat untuk menenun.

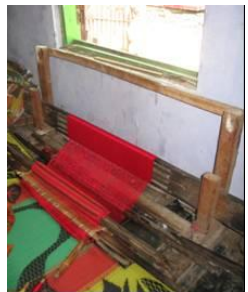

Sumber: Penelitian 2009

Bagian-bagian dalam gedogan terdiri atas:

- Por, ialah alat yang berfungsi sebagai penahan pinggang penenun. Bahannya terbuat dari kayu dan tali rami atau tali tambang.
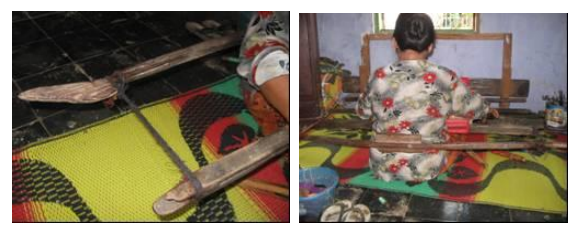

Sumber: Penelitian 2009

- Suri, bentuknya menyerupai sisir, fungsinya untuk memisahkan lusi atas dan lusi bawah.

- Dayan (papan), gunanya untuk menarik lurus benang.

- Apit, alat untuk menggulung tenunan yang sudah jadi, letaknya di depan perut penenun.

\section{Teknik Pembuatan}

Pengrajin tenun di Desa Juntikebon terbagi atas pengrajin murni dan pengrajin sambilan. Pengrajin murni adalah pengrajin yang pekerjaan sehari-harinya menenun, selain aktivitas rumah tangga yang sudah menjadi kewajibannya. Adapun pengrajin sambilan adalah mereka yang sehari-harinya menggeluti pekerjaan bertani dan di kala senggang diisi dengan kegiatan bertenun.

Sejak awal tenun gedogan ada, pengrajin tenun adalah kaum perempuan. Bedanya, kalau dulu usia 
pengrajin relatif muda, berkisar 20 tahunan, sekarang relatif tua, di atas 45 tahun. Pengrajin yang sekarang adalah juga pengrajin yang dulu. Hal ini terjadi karena tidak ada regenerasi di kalangan pengrajin.

Pengrajin murni menenun dalam dua paruh waktu. Pagi hari sekitar pukul 09.00 WIB - 11.00 WIB dan siang hari pukul $13.00 \mathrm{WIB}-15.00$ WIB. Antara pukul $11.00 \mathrm{WIB}-13.00$ WIB istirahat, sedangkan waktu sebelum dan sesudahnya adalah waktu untuk aktivitas rumah tangga dan keperluan lain. Adapun pengrajin sambilan akan menenun bilamana mereka memiliki waktu senggang sekitar 2 jam, dan. biasanya dilakukan seusai sholat dhuhur. Adapun pagi hari mereka ke sawah. Bagi seorang pengrajin, waktu 2 jam untuk menenun dirasakan cukup. Hal ini lebih disebabkan karena keterbatasan tenaga. Menurut informan, usia 45 tahun ke atas, duduk menyelonjor dengan pinggang ditahan alat por membuatnya sering merasa sakit pada bagian pinggang, sehingga kegiatan bertenun terpaksa dihentikan.

Ilmu dalam bertenun dimiliki pengrajin secara turun-temurun. Cara mempelajari adalah dengan melihat atau ikut membantu ibunya yang sedang menenun. Dengan demikian mata dan tangan menjadi akrab dengan pekerjaan menenun. Pekerjaan dari mulai memper-siapkan benang hingga menenun biasa dilakukan seorang diri. Menenun dilakukan di ruangan yang terang dan leluasa, seperti di teras atau ruang tamu. Selain terang, juga cukup udara, dan ada "teman" ngobrol agar pengrajin tidak merasa jenuh. Kalau pengerjaannya di teras dan apabila penenun akan menghentikan pekerjaan maka penenun akan meninggalkan alatnya di tempat setelah menutup terlebih dahulu dengan selembar kain supaya tidak berdebu. Sementara itu hanya tempat benang yang dibawa ke rumah. Kalau pengerjaannya dilakukan di dalam rumah, usai dipakai, alatnya dibiarkan begitu saja. Tidak perlu ditutup dengan kain karena dianggap tidak banyak debu. Cara untuk menjaga agar alat tidak cepat rusak ialah alat dijaga jangan sampai terkena air. Alat tenun yang didominasi dari bahan kayu akan mudah keropos bila terkena air.

Secara garis besar, untuk mewujudkan sehelai selendang dengan alat tenun gedogan melalui tahapan berikut:

- Nglerek ke pajal, yaitu menggulung benang ke pajal, lamanya berkisar $1 / 2$ - 1 jam. Benang ini berfungsi sebagai benang pakan.

- Nglerek ke kluntungan, selain menggulung benang ke pajal, juga menggulung benang ke kluntungan. Benang ini berfungsi sebagai benang lusi.

- Mani, menyusun benang sesuai ukuran kain yang diinginkan dari kluntungan ke pamanen, lamanya berkisar 2 jam

- Nenun, menenun sehelai selendang memerlukan waktu paling cepat 1 minggu dan paling lama 10 hari.

Keseluruhan proses dari mulai nglerek sampai menenun memakan waktu sekitar dua minggu.

Meskipun relatif sederhana, tenun gedogan memiliki ragam hias. Ragam hias atau disebut juga ornamen adalah hiasan, yaitu sesuatu yang ditambahkan pada suatu benda dengan maksud untuk memperindah benda 
tersebut. Ragam hias dapat berupa warna, tekstur, atau motif. Ragam hias pada tenun gedogan adalah ragam hias geometris yaitu berbentuk persegi dan wajik, dengan tambahan benang yang disulurkan.

Kain tenun gedogan didominasi oleh warna terang atau cerah. Antara lain ada warna merah, orange, pink (merah muda), hijau, dan kuning. Merunut perjalanan sejarah gelombang kedatangan etnik Tionghoa ke Indonesia, ragam hias dan tata warna tenun gedogan tersebut bukan tidak mungkin sekecil apapun mendapat pengaruh dari budaya Cina. Mengacu pada kitab-kitab sejarah Cina kuno, di dalamnya banyak sekali bagian yang memuat berita tentang telah adanya pemukiman golongan etnik Tionghoa di sepanjang Kepulauan Nusantara khususnya Pantai Utara Jawa, sejak 300 tahun sebelum Masehi (Dahana, 2005: 2). Dalam budaya Cina, garisgaris geometris bukanlah sekadar bentuk yang indah dan artistik, tetapi di dalamnya tercermin bentuk-bentuk kekuatan alam dan kebesaran Tuhan. Dalam hal warna, warna merah mencolok merupakan simbol kekuatan hidup dan kejayaan. Melalui simbol, terkandung harapan bahwa sebesar apapun masalah yang menghadang harus dihadapi dengan kuat demi meraih kejayaan. Warna-warna cerah lainnya adalah simbol sifat yang lebih terbuka dan cepat menerima perubahan. Sifat-sifat yang menjadi ciri masyarakat pesisir yang berlaku sebaliknya dengan masyarakat yang tinggal di pedalaman. Keterbukaan tersebut terkondisi oleh lingkungan geografis yang membiarkan orang masuk secara bergantian melalui pelayaran. Ragam hias lainnya berupa koncir atau jimbris, yang peletakannya pada kedua tepi lebar kain. Jimbris ada yang dibuat langsung pada kain dan ada yang ditambahkan pada kain.

Jimbris tambahan berupa sehelai benang yang dilipat kemudian dijahitkan pada bagian tepi lebar kain. Manakala selendang dengan jimbris tambahan akan dipakai, maka bagian tengah lipatan benang digunting terlebih dulu.

\section{Sistem Produksi, Konsumsi, dan Distribusi}

Pengrajin tenun gedogan di Juntikebon adalah pengrajin yang bekerja di rumah-rumah. Mereka merupakan pengrajin yang sama dari tahun ke tahun. Kondisi tersebut menggambarkan bahwa tidak ada regenerasi penenun di dalam satu keluarga. Tidak heran kalau setiap penenun harus mengerjakan semua tahapan sendiri, dari mulai menyiapkan benang sampai menenunnya, hingga menghasilkan tenun berupa selendang. Dengan beban seperti itu seorang pengrajin yang hanya mem-fokuskan pada pekerjaan menenun mampu menghasilkan rata-rata dua helai selendang dalam sebulan. Dengan kata lain, satu helai selendang dikerjakan dalam kisaran waktu dua minggu. Lain lagi bagi penenun yang hanya menenun manakala memiliki waktu luang, sudah pasti waktu pengerjaan sehelai selendang akan lebih lama.

Satu helai selendang dijual kepada bakul dengan harga berkisar Rp70.000,- sampai Rp 90.000,-. Oleh bakul selendang dijual kepada peminat tenun dengan harga berkisar $\mathrm{Rp}$. 85.000,- sampai Rp 110.000,-. Harga sehelai selendang bukan terletak pada warnanya melainkan pada ragam hias 
jimbris. Jimbris yang dibuat langsung pada saat menenun harganya akan lebih mahal dibandingkan dengan jimbris tambahan. Penyebabnya adalah benang lusi yang digunakan lebih panjang hingga sudah pasti proses pembuatan menjadi lebih lama. Adapun jimbris tambahan dijahitkan pada kain dengan jarum tangan seusai kain tenun jadi. Bakul biasanya menyimpan selendang 3 sampai 10 helai. Pada masa sehabis panen, biasanya ada pelanggan dari Desa Semirang dan Pekandangan yang menyambanginya. Mereka membeli untuk kemudian menjualnya.

Ada perbedaan antara pengrajin dulu dan sekarang. Dulu, pengrajin cukup bermodalkan tenaga. Artinya, pengrajin tidak perlu membeli benang untuk tenun melainkan pemilik modal yang membeli benangnya. Pemilik modal menyerahkan benang pada pengrajin untuk ditenun. Manakala tenunan sudah jadi lalu diserahkan kembali kepada pemilik modal dan diberinya pengrajin tersebut upah. Sekarang, pengrajin bukan saja sekadar bermodalkan tenaga melainkan juga benang. Manakala tenun sudah jadi, tenun dijual kepada bakul.

Penggunaan tenun dulu dan sekarang berbeda. Dulu, kain tenun gedogan digunakan untuk memenuhi kebutuhan sendiri. Utamanya sebagai alat gendong. Alat untuk menggendong anak balita (di bawah usia lima tahun) atau menggendong cepon/wakul (tempat sayuran yang terbuat dari bambu) atau juga karung. Selain itu, ada kain tenun yang digunakan untuk pengobatan. Kain yang dimaksud adalah kain dengan dasar warna putih berloreng hitam. Jenis kain seperti itu disebut sewet wewe 'selendang makhluk halus berkelamin perempuan'. Sewet wewe digunakan untuk mengobati bayi atau anak-anak yang sedang sakit. Umumnya sakit panas. Cara penggunaannya dengan menyelimutkan pada badan si bayi atau anak. Dengan cara itu dipercaya sakitnya akan sembuh. Konon motif loreng hitam ditakuti oleh makhluk halus. Oleh karena itu penggunaan kain loreng dimaksudkan untuk menakutnakuti atau mengusir makhluk halus agar jangan mengganggu bayi dan anak-anak. Seiring dengan banyaknya orang di desa dan sekitarnya yang telah memiliki kain tenun selain juga alat gendong produk pabrikan semakin banyak, maka pengrajin menjadi kerepotan dengan hasil produksinya. Apalagi tenaga pemasaran yang diharapkan bisa memasarkan produksinya keluar dari daerahnya ternyata tidak ada. Apa yang terjadi kemudian adalah satu demi satu pengrajin meng-hentikan kegiatannya. Saat ini hanya tersisa beberapa orang pengrajin dan itupun hanya satu orang yang benar-benar hanya memfokuskan diri sebagai pengrajin. Pembeli sudah bukan lagi penduduk setempat melainkan dari desa tetangga yang membeli untuk kemudian menjualnya dan "satu dua" orang dari luar desa. Pembeli dari luar desa itulah yang kemudian meluaskan fungsi kain tenun gedogan. Dari selendang sebagai alat gendong konon berubah fungsi menjadi hiasan dinding, taplak meja, sarung bantal, tirai, dan bahkan bahan pakaian, bergantung kreativitas pembelinya.

Ada dua cara yang ditempuh oleh pengrajin dalam menyalurkan hasil produksi. Pertama, langsung menjual kepada pembeli yang datang 
padanya. Kedua, melalui bakul. Bakul membeli tenun dari pengrajin kemudian menjualnya kepada peminat tenun, yaitu bisa bakul lagi atau orang kebanyakan. Bakul biasanya orang yang bermodal cukup besar. Oleh karena itu setiap pengrajin menghasilkan helai demi helai selendang akan langsung dibelinya. Adanya bakul, di satu sisi menguntungkan pengrajin karena modal akan cepat berputar. Namun demikian di sisi lain pengrajin tidak bisa menjual produknya dengan harga yang maksimal. Selendang yang dijual pengrajin kepada bakul tanpa kemasan, sekadar dilipat. Sementara itu, bakul menjual selendang kepada peminat tenun dalam keadaan sudah terlipat rapih dan dikemas dalam kemasan plastik.

Perawatan tenun gedogan tidak sulit. Tenun gedogan boleh dicuci dengan jenis sabun apapun dan tidak akan memudar warnanya meski dijemur di tempat panas sekalipun. Selain itu manakala dicuci warnanya tidak akan luntur dan setelahnya kain tidak akan kerut.

\section{PENUTUP}

Tenun Indonesia seperti halnya kain tenun gedogan, adalah bagian dari kebudayaan Indonesia yang beragam coraknya. Selama berabad-abad kepandaian dalam bertenun diwariskan dari generasi ke generasi. Sampailah kemudian kepandaian itu pada pengrajin tenun gedogan di Desa Juntikebon, Kecamatan Juntinyuat, Kabupaten Indramayu.

Bagaimana proses sampai terwujudnya kain tenun gedogan adalah suatu kerja dan karya yang adiluhung.
Dari kacamata kekinian, melalui kesederhanaan dalam bahan dan cara pembuatan alat, cara penggunaan alat, dan cara perolehan ilmunya, terwujud helaian demi helaian tenunan selendang. Kain berupa selendang tersebut sangat diperlukan sebagai alat gendong dan bahkan media pengobatan. Selanjutnya selendang tenun dapat dikembangkan fungsinya selaras kreativitas peminatnya.

Sangat disayangkan bahwa buah karya tersebut secara perlahan-lahan "menghilang". Nasib tenun gedogan seperti sekarang ini tentu saja tidak terlepas dari berbagai faktor yang mempengaruhinya. Ada empat faktor yang dominan terkait dengan hasil produksi tenun gedogan. Keempat faktor tersebut ialah: faktor pola kerja, waktu, kesenjangan antara produsen dan konsumen, dan penyebaran produksi.

- Pola kerja: mayoritas pengrajin menempatkan pekerjaan menenun sebagai pekerjaan sampingan, bukan utama.

- Waktu: lamanya waktu untuk menyelesaikan satu jenis produk bervariasi bergantung waktu yang dimiliki. Kelak apabila jumlah pembeli ada peningkatan maka diperlukan disiplin waktu dalam menenun.

- Kesenjangan antara produsen dan konsumen: pengrajin belum berorientasi pada keinginan pasar. "Jalan di tempat" dengan selendangnya sehingga belum memberikan pengaruh yang cukup baik pada peminat tenun.

- Penyebaran produksi: teknik pemasaran tenun gedogan sangat sederhana, yaitu menunggu datangnya pembeli yang waktunya 
tidak pasti tapi harga bisa tinggi, atau menjual pada bakul (pembeli sekaligus penjual di desa itu) tapi harga tidak maksimal.

Keempat faktor tersebut kiranya akan menjadi masalah yang berkepanjangan selama pekerjaan menenun hanya menjadi pekerjaan sampingan. Tidak heran meskipun di atas kertas tertulis angka 65 pengrajin namun angka untuk pengrajin tenun gedogan sulit untuk dapat diketahui secara pasti. Masalah juga tidak akan pernah berhenti selama pengrajin tidak memiliki jadwal yang baku dan memanfaatkan waktu dengan maksimal; selama pengrajin tidak berinovasi dengan ragam bentuk demi memenuhi keinginan pasar; dan selama pengrajin tidak memiliki tenaga pemasaran yang handal.

Terkait dengan kondisi tenun gedogan pada saat ini dan demi memacu ekonomi kreatif yang berbasis budaya maka perlu ada upaya dari pihak terkait untuk:

- Merevitalisasi (memberi daya) tenun gedogan agar karya budaya itu bisa berkembang lagi.

- Mengembangkan jiwa wiraswasta di kalangan kaum muda, khususnya di bidang pertenunan.

- Regenerasi pengrajin melalui pelatihan-pelatihan.

- Menunjang terciptanya iklim dunia usaha yang lebih produktif dan kompetitif.

- Menyediakan sarana dan prasarana untuk informasi, baik untuk kepentingan produsen maupun konsumen.
Upaya di atas dilanjutkan lagi dengan langkah-langkah berikut agar tenun gedogan tetap lestari:

- Mensosialisasikan tenun gedogan melalui komitmen pemakaian tenun sebagai benda koleksi di kantorkantor dan sekolah.

- Memasukkan teknologi tenun sebagai kurikulum pendidikan kriya.

- Lomba desain motif untuk kain tenun.

- Lomba kreativitas berbahan dasar tenun gedogan.

- Membawa tenun gedogan dalam ajang pameran sebagai upaya memperkenalkan kepada masyarakat luas, khususnya generasi muda.

- Mengadakan kegiatan lawatan budaya dengan mengajak siswa setingkat SLTA mengunjungi sentra tenun. Dari hasil kunjungan, siswa meng-apresiasi lewat acara diskusi atau lomba mengarang.

- Dan, sebelum segalanya hilang dari pemiliknya, museum tenun menjadi salah satu alternatif bagi generasi ke depan untuk mengenal dan membanggakan budayanya.

Pengrajin, pemerhati, dan pemerintah sama-sama berperan untuk menjaga agar kesinambungan itu tetap ada. Tenun bukan sekadar hidup tapi tenun adalah karya sosial, budaya, dan ekonomi.

\section{DAFTAR PUSTAKA}

Arifin, Zainal. 2005.

"Kain-kain Adat Indonesia

Makna dan Fungsinya". Makalah di-sampaikan pada Seminar Tekstil Tradisional yang Dipengaruhi Oleh Budaya Cina. 
Direktorat Tradisi Direktorat Jenderal Nilai Budaya, Seni, dan Film Departemen Ke-budayaan dan Pariwisata Museum Nasional. November.

As., Sumijati. 2007.

Penelitian dan Penulisan Ilmiah. Fakultas Ilmu Budaya Universitas Gajah Mada. Yogyakarta.

Dahana. 2005.

Gelombang Migrasi Etnik

Tionghoa ke Indonesia. Makalah Seminar Tekstil Tradisional yang Di-pengaruhi oleh Budaya Cina. Direktorat Tradisi Direktorat Jenderal Nilai Budaya, Seni, dan Film Departemen Kebudayaan dan Pariwisata. Jakarta.

Dinas Koperasi dan Pemberdayaan. 2006.

Daftar Isian Potensi Desa Pemerintah Kabupaten Indramayu.

Disbudpar Dirjen Nilai Budaya, Seni dan Film Direktorat Tradisi. 2008.
Inventarisasi Aspek-Aspek
Tradisi (Tenun Tradisional). Jakarta.

Isniawati. Nina. 1988.

Simbolisme dalam Batik Keratonan Cirebon. FISIP UNPAD. Bandung.

Kartiwa, Suwarti dan Arifin, Zaenal. 2005.

"Fungsi dan Makna Kain Tradisional yang Dipengaruhi Budaya Cina". Makalah dalam Seminar Tekstil Tradisional yang Dipengaruhi Oleh Budaya Cina. Direktorat Tradisi Direktorat Jenderal Nilai Budaya, Seni, dan
Film Departemen Kebudayaan dan Pariwisata. Jakarta.

Kwan Hwie Liong. 2005.

"Kain dan Pakaian Tradisional Indonesia yang Dipengaruhi Budaya Tionghoa". Makalah Seminar Tekstil Tradisional yang Dipengaruhi oleh Budaya Cina. Direktorat Tradisi Direktorat Jenderal Nilai Budaya, Seni, dan Film Departemen Kebudayaan dan Pariwisata. Jakarta.

Kadir, Azhari. 2006.

Tapis Kain Tenun dan Sulaman Tradisional Lampung. Bandar Lampung.

Saptono, Nanang. 2003.

"Tenun dalam Hubungannya Dengan Proses Perubahan Budaya". Makalah dalam rangka Seminar Sehari Upaya Pelestarian Seni Tenun Tradisional dalam Era Teknologi. Balai Pengelolaan Museum Negeri Sri Baduga. Bandung.

Supriyo. S Teks. 2003.

"Sejarah Perkembangan

Teknologi Tenun Tradisional di Jawa Barat". Makalah Seminar tentang Upaya Pelestarian Seni Tenun Tradisional dalam Era Teknologi. Balai Pengelolaan Museum Negeri Sri Baduga. Bandung.

Tresnasih, Ria Intani. 2005.

Menelusuri Kejayaan Tenun Majalaya. BKSNT. Bandung.

Z., Ferina. 1988.

Tinjauan Kain Tapis Lampung. Jurusan Desain Fakultas Seni Rupa dan Desain ITB. Bandung. 